\title{
DEMAM KOREA: MINAT BELI TERHADAP PRODUK KECANTIKAN KOREA $($ K-BEAUTY)
}

\author{
Jenia Hanindita Rahmawati \\ Universitas Islam Negeri Sunan Ampel Surabaya \\ hrienia4@gmail.com \\ Muhamad Ahsan \\ Universitas Islam Negeri Sunan Ampel Surabaya \\ m.ahsan@uinsby.ac.id
}

\begin{abstract}
This research aims to examine the effect of brand image, celebrity endorser, country of origin and electronic word of mouth on buying interest in Korean beauty products (K-Beauty). The method used is quantitative associative. The sampling technique used is accidental sampling as many as 108 respondents. Data was collected by distributing online questionnaires via a google form. The collected data was analyzed using Structural Equation Modeling (SEM) which consists of two stages, namely the measurement model and the structural model with IBM SPSS AMOS software version 20 and index number analysis as descriptive analysis. The results showed that brand image has a positive and significant effect on buying interest in Korean beauty products (K-Beauty). While celebrity endorsers, country of origin and electronic word of mouth have no effect on buying interest in Korean beauty products (K-Beauty).
\end{abstract}

Keywords: brand image; buying interest; celebrity endorser; country of origin; electronic word of mouth.

\section{PENDAHULUAN}

Di Indonesia, pertumbuhan industri kosmetik terus mengalami peningkatan setiap tahunnya (Gareta, 2021). Meningkatnya pertumbuhan industri kosmetik berbanding lurus dengan tingginya permintaan produk kecantikan. Produk kecantikan tidak hanya menjadi pemenuhan keinginan (wants) saja, melainkan telah menjadi kebutuhan (needs). Peningkatan industri kosmetik di Indonesia bukan disebabkan oleh kosmetik lokal, melainkan kosmetik yang diimpor. Hal tersebut terjadi karena konsumen di Indonesia lebih menyukai produk kosmetik global, terutama asal Korea Selatan dibandingkan produk lokal (Zapclinic.com, 2020). Fenomena tersebut menunjukkan bahwa konsumen di Indonesia memiliki preferensi yang tinggi terhadap produk kecantikan asal Korea Selatan. Tingginya preferensi tersebut mengindikasikan adanya minat beli yang tinggi (Ferdinand, 2014).

Riset tentang minat beli menjadi penting dilakukan karena dapat memicu meningkatnya penjualan produk dan bahan evaluasi bagi perusahaan untuk mengetahui tren pasar dan menentukan positioning produk. Minat beli timbul karena (1) adanya pengaruh strategi pemasaran, dimana pemasar berusaha memengaruhi konsumen seperti memperkenalkan keunggulan produk yang akan mendongkrak brand image sebuah produk serta melakukan kegiatan promosi dengan memanfaatkan celebrity endorser, (2) pengaruh dari lingkungan karena sikap dari orang lain dalam memberikan ulasan positif sebuah produk seperti word of mouth (Assael, 2002) yang kini beralih menjadi electronic word of mouth karena tingginya pengguna internet (64\%) di Indonesia (Pradana, 2020). Faktor lain yang dapat memengaruhi minat beli selain tiga yang telah disebutkan sebelumnya adalah demam budaya yang sedang melanda semisal sinetron India, atau drama Korea. Sehingga, banyak konsumen yang ingin mengetahui lebih banyak tentang budaya dari negara yang memproduksi sinetron atau drama tersebut. Country of origin juga dapat memengaruhi pengambilan keputusan seseorang baik secara langsung atau tidak (Kotler \& Keller, 2007).

Hasil riset terdahulu yang fokus pada minat beli menunjukkan, brand image berpengaruh positif dan signifikan (Agatha et al., 2019; Ambarwati, 2020; Benowati \& Purba, 2020; Berlianto, 2019; Cahyaningrum, 2020; Juliana et al., 2018; Qonita, 2019; Yusron et al., 2019); brand image berpengaruh signifikan (Imaningsih \& Rianty, 2018; Santoso et al., 2019). Akan tetapi temuan lain 
Jenia Hanindita Rahmawati \& Muhamad Ahsan. Demam Korea: Minat Beli terhadap Produk Kecantikan Korea (K-Beauty)

menunjukkan brand image berpengaruh positif namun tidak signifikan (Ramlawati \& Lusyana, 2020). Riset terdahulu yang menguji pengaruh variabel celebrity endorser pada minat beli menunjukkan hasil yang positif dan signifikan (Cahyaningrum, 2020; Juliana et al., 2018; Ramlawati \& Lusyana, 2020; Yusron et al., 2019); tidak berpengaruh pada minat beli (Qonita, 2019). Riset variabel country of origin terhadap minat beli juga telah dilakukan. Hasilnya menunjukkan pengaruh positif dan signifikan (Budiarti, 2020; Cahyaningrum, 2020); country of origin berpengaruh signifikan (Imaningsih \& Rianty, 2018); tidak berpengaruh pada minat beli (Berlianto, 2019). Sedangkan pengaruh variabel electronic word of mouth pada minat beli positif dan signifikan (Agatha et al., 2019; Ambarwati, 2020; Benowati \& Purba, 2020; Cahyaningrum, 2020; Husna \& Dirgantara, 2018). Inkonsistensi temuan pada riset terdahulu menunjukkan masih terbukanya peluang melakukan pengujian ulang terhadap variabel yang memengaruhi minat beli, khususnya pada produk kosmetik.

Berbagai upaya dilakukan perusahaan untuk menaikkan minat beli konsumen. Salah satu caranya membangun citra merek yang kuat dan positif agar mudah diingat dan familiar di benak konsumen sehingga dapat menstimulus konsumen untuk membeli (Fauziah \& Mubarok, 2019). Cara lain perusahaan untuk meningkatkan minat beli konsumen adalah dengan memanfaatkan selebriti terkenal (celebrity endorser) dalam mempromosikan produknya agar mendapat perhatian konsumen. Semakin terkenal celebrity endorser yang mempromosikan maka semakin besar pengaruhnya terhadap minat beli konsumen (Ramlawati \& Lusyana, 2020). Hal tersebut karena selebriti merupakan figur yang populer dan menjadi pusat perhatian. Selain brand image dan celebrity endorser, kecanggihan teknologi informasi juga dimanfaatkan untuk menaikkan minat beli konsumen (Ambarwati, 2020).

Seorang calon konsumen memiliki kecenderungan mencari informasi yang dibutuhkan sebelum melakukan transaksi. Informasi bisa diperoleh dari ulasan atau review melalui konsumen yang pernah menggunakan produk tertentu. Makin banyak ulasan positif pada sebuah produk, semakin tinggi juga minat beli calon konsumen (Ambarwati, 2020). Tidak hanya itu, image negara asal juga turut memengaruhi minat beli seorang konsumen sebelum memutuskan untuk membeli. Calon konsumen memperhatikan negara asal karena negara asal dapat membangun persepsi konsumen tentang kualitas produk (Berlianto, 2019). Pengetahuan konsumen terhadap country of origin dapat disebabkan oleh trend budaya pop yang sedang melanda sehingga konsumen memiliki persepsi positif pada produk dari negara tersebut. Semakin kuat tren budaya yang sedang melanda maka semakin besar keinginan calon konsumen untuk membeli.

Hasil prasurvei, menunjukkan bahwa dengan gaya hidup yang sederhana dan uang saku rata-rata kurang dari Rp500.000 setiap bulannya, mahasiswa UIN Sunan Ampel Surabaya memiliki konsumsi yang tinggi terhadap produk kecantikan Korea (K-Beauty) dengan rata-rata lebih dari 3 kali pembelian. Konsumsi terhadap produk kecantikan asal Korea juga disebabkan karena demam Korea sedang melanda. Penelitian ini bertujuan menguji pengaruh brand image, celebrity endorser, country of origin dan electronic word of mouth terhadap minat beli mahasiswa pada produk kecantikan Korea.

\section{KAJIAN PUSTAKA DAN PENGEMBANGAN HIPOTESIS}

\section{Minat Beli}

Minat beli adalah keinginan konsumen untuk melakukan pembelian karena adanya respon dari suatu obyek (Kotler \& Keller, 2009); rencana konsumen untuk membeli sejumlah merek produk yang dibutuhkan pada waktu tertentu (Howard \& Sheth, 1969). Pendapat lain menyampaikan, minat beli adalah keinginan konsumen untuk memiliki produk karena adanya pengaruh terhadap kualitas produk serta informasi seputar produk (Durianto, 2013). Indikator minat beli terdiri dari: (1) intensitas mencari informasi, (2) ingin segera membeli, (3) keinginan preferensial (ferdinand, 2014).

\section{Brand Image}

Brand Image merupakan persepsi atau pemahaman konsumen pada suatu merek produk yang tergambar lewat asosiasi merek yang terdapat diingatannya (Keller, 2013). Citra merek dijadikan pedoman atau acuan bagi konsumen dalam mencoba dan menggunakan sebuah produk. Konsumen yang tidak mempunyai pengalaman terhadap sebuah produk memiliki kecenderungan yang besar 
untuk memilih produk atau merek yang terkenal. Konsumen beranggapan jika merek yang terkenal dapat diandalkan, mempunyai kualitas yang bagus serta kemudahan dalam mendapatkannya (Aaker, 1997). Untuk mengukur variabel brand image, indikator yang digunakan diantaranya: (1) strengthness/kekuatan, (2) uniqueness/keunikan, (3) favorable/keunggulan (keller, 2013).

\section{Celebrity Endorser}

Celebrity endorser merupakan seseorang yang terkenal yang dijadikan sebagai pendukung suatu merek produk dalam iklan (Shimp, 2003). Definisi lain celebrity endorser, seorang figure yang menarik dan populer sebagai narasumber untuk menyampaikan pesan guna mendapat perhatian lebih dan diingat (Kotler \& Keller, 2009). Bentuk dukungan selebriti dapat berbentuk implisit seperti 'saya memakai produk ini' dan dukungan eksplisit seperti 'saya mendukung produk ini' serta dukungan imperatif seperti 'Anda harus memakai produk ini'. Bentuk dukungan lain dapat berupa presentasi bersama produk yang diendorse (McCracken, 1989). Indikator yang digunakan untuk mengukurnya diantaranya adalah (1) trustworthiness/kepercayaan, (2) expertise/keahlian, (3) attractiveness/daya tarik (Royan, 2004).

\section{Country of Origin}

Country of Origin ialah persepsi individu pada produk yang dipicu darimana asal negaranya (Kotler \& Keller, 2007). Country of origin digunakan untuk penentuan kualitas sebuah produk ketika konsumen belum melakukan pembelian. Konsumen akan melihat image suatu negara untuk memprediksi kualitas sebuah produk. Karena konsumen tidak bisa menentukan atau menilai bagaimana kualitas yang dimiliki suatu produk sebelum mengkonsumsinya (Lusk et al., 2006). Indikator yang digunakan untuk mengukurnya di antaranya: (1) inovasi negara dalam berproduksi, (2) kemajuan teknologi negara asal, (3) desain produksi, (4) kreativitas berproduksi (5) kualitas produksi, (6) prestise yang dimiliki negara asal, (7) citra negara asal sebagai negara maju (Yasin et al., 2007).

\section{Electronic Word of Mouth}

Electronic Word of Mouth adalah pendapat yang bernilai positif atau negatif dari sebuah produk di internet yang dibuat oleh konsumen yang pernah menggunakan, konsumen aktual maupun konsumen potensial (Hennig-Thurau et al., 2004); merupakan media komunikasi dalam berbagi informasi sesama konsumen yang belum mengenal bahkan tidak bertemu sebelumnya tentang produk atau jasa yang sudah dikonsumsi (Gruen et al., 2006). Indikator yang digunakan untuk mengukurmya diantaranya: (1) platform assistance (bantuan platform atau media), (2) venting negative feelings (melampiaskan perasaan negatif), (3) concern for other consumers (kepedulian pada orang lain), (4) extraversion/positive self-enhancement (ekspresi perasaan positif), (5) social benefits (manfaat sosial), (6) economic incentive (insentif ekonomi), (7) helping the company (membantu perusahaan), (8) advice seeking (mencari saran) (Hennig-Thurau et al., 2004).

\section{Pengaruh Antar Variabel}

Citra merek dijadikan pedoman atau acuan bagi konsumen ketika ingin mencoba dan menggunakan suatu produk (Aaker, 1997). Merek yang bercitra positif berpeluang besar menarik perhatian calon konsumen yang dapat menimbulkan minat beli. Didukung oleh penelitian Juliana et al., (2018), Agatha et al., (2019), Berlianto (2019), Qonita (2019), Yusron et al., (2019), Ambarwati (2020), Benowati \& Purba (2020), Cahyaningrum (2020) yang menyatakan, bahwa pengaruh yang dimiliki brand image pada minat beli positif dan signifikan. Serta penelitian Imaningsih \& Rianty (2018), Santoso et al., (2019) menyatakan, brand image juga signifikan memengaruhi minat beli.

H1: Brand Image berpengaruh positif dan signifikan terhadap minat beli produk kecantikan Korea (K-Beauty).

Ketenaran atau kepopuleran selebriti dapat menimbulkan keinginan seseorang untuk mencontoh gaya hidupnya. Penggunaan celebrity endorser, persepsi dan sikap konsumen pada suatu produk akan bertambah dan dapat meningkatkan penjualan (Shimp, 2003). Statemen yang disampaikan tersebut diperkuat oleh hasil penelitian Juliana et al., (2018), Yusron et al., (2019), Cahyaningrum (2020), 
Jenia Hanindita Rahmawati \& Muhamad Ahsan. Demam Korea: Minat Beli terhadap Produk Kecantikan Korea (K-Beauty)

Ramlawati \& Lusyana (2020) yang menyatakan celebrity endorser mempunyai pengaruh positif dan signifikan pada minat beli.

H2: Celebrity Endorser berpengaruh positif dan signifikan terhadap minat beli produk kecantikan Korea (K-Beauty).

Negara asal dapat memberi persepsi kepada konsumen mengenai kualitas produk yang dapat memengaruhi pengambilan keputusan seseorang baik secara langsung atau tidak (Kotler \& Keller, 2007). Hasil penelitian Budiarti (2020), Cahyaningrum (2020) menyatakan, country of origin mempunyai pengaruh positif dan signifikan pada minat beli. Serta penelitian Imaningsih \& Rianty (2018) menyatakan country of origin memiliki pengaruh yang signifikan pada minat beli.

H3: Country of Origin berpengaruh positif dan signifikan terhadap minat beli produk kecantikan Korea (K-Beauty).

Adanya attitudes of other seperti sikap positif atau negatif orang lain terhadap suatu produk dapat memengaruhi minat beli seseorang (Kotler \& Keller, 2009). Semakin positif review atau ulasan yang diberikan seseorang di internet berbanding lurus dengan tingginya minat beli. Hal ini didukung oleh penelitian Husna \& Dirgantara (2018), Agatha et al., (2019), Ambarwati (2020), Benowati \& Purba (2020), Cahyaningrum (2020) bahwa electronic word of mouth positif dan signifikan memengaruhi minat beli.

H4: Electronic Word of Mouth berpengaruh positif dan signifikan terhadap minat beli produk kecantikan Korea (K-Beauty).

\section{METODE PENELITIAN}

Pendekatan penelitian ini kuantitatif asosiatif. Populasinya ialah mahasiswa UIN Sunan Ampel Surabaya. Pengambilan sampel dilakukan dengan teknik accidental sampling. Variabel eksogen penelitian adalah brand image (BI), celebrity endorser $(\mathrm{CE})$, country of origin $(\mathrm{COO})$ dan electronic word of mouth (EWOM). Sedangkan variabel endogennya minat beli (MB). Pengukuran yang digunakan skala Likert dengan interval 1-10. Data dikumpulkan dengan menyebar kuesioner secara online kepada responden melalui google form selama bulan Januari 2021 - Februari 2021. Jumlah sampel yang digunakan sebanyak 108 sampel dari 134 sampel yang di dapat, karena 26 sampelnya tidak sesuai kriteria. Kriteria yang digunakan untuk memfilter sampel terpilih diantaranya, mengetahui produk kecantikan asal Korea Selatan (K-Beauty), memiliki pilihan produk $K$-Beauty yang diminati, pernah menonton celebrity endorser produk $K$-Beauty dan mengetahui produk $K$ Beauty dari media sosial. Data yang sudah terkumpul dianalisis menggunakan Structural Equation Model (SEM). Terdapat dua tahapan analisis yang dilakukan dalam SEM yaitu model pengukuran dan model struktural dengan bantuan program IBM SPSS AMOS versi 20. Analisis lain yang digunakan adalah angka indeks sebagai analisis dekriptif.

\section{HASIL DAN PEMBAHASAN}

\section{Karakteristik Responden}

Karakteristik responden pada riset ini terdiri dari gender, usia, penghasilan orang tua, besarnya uang saku, merek kosmetik yang diminati, jenis produk yang diminati dan sumber informasi yang didapat. Responden penelitian terdiri dari perempuan sebanyak 107 responden (99\%) sedangkan 1 responden (1\%) adalah laki-laki dengan usia rata-rata 20-22 tahun sebanyak 97 responden (90\%). Penghasilan orang tua responden paling banyak pada rentang Rp1.000.000-Rp3.000.000 ada 46 responden (43\%) sedangkan uang saku responden per bulan paling banyak pada rentang $<\mathrm{Rp500.000} \mathrm{ada} 64$ responden (59\%). SOME BY MI dan Nature Republic adalah brand produk $K$-Beauty yang paling banyak diminati, masing-masing sebanyak 21 responden (19\%) dan 19 responden (18\%). Jenis produk yang paling banyak diminati adalah serum dengan jumlah 48 responden (44\%). Selain itu, sebanyak 76 
responden $(70 \%)$ mengetahui produk $K$-Beauty dari Instagram, 23 responden $(21 \%)$ dari Youtube, 5 responden (5\%) dari Twitter, 4 responden $(4 \%)$ dari Tik Tok.

\section{Uji Model pengukuran SEM: Uji Validitas}

Untuk mengukur validitas kuesioner digunakan analisis faktor konfirmatori atau dalam istilah asing disebut Confirmatory Factor Analysis (CFA). Dengan tujuan mengkonfirmasi apakah variabel indikator yang dipakai mampu mengkonfirmasi sebuah konstruk serta mendapatkan konstruk yang fit. Ketentuan loading factor berdasarkan besaran jumlah sampel menurut Hair et al., (2018) ialah 0,55. Maka item dinyatakan valid apabila nilai loading factor $\geq 0,55$. Setelah dilakukan uji validitas, terdapat empat item yang tidak valid karena nilai loading factornya $\leq 0,55$ yaitu loading factor item BI1.3 0,119, loading factor BI3.1 0,346, loading factor COO6.1 0,498 dan loading factor EWOM1.1 0,529. Maka item tersebut harus di drop dari model dan tidak di ikutkan pada proses selanjutnya. Berikut hasil revisi gambar model:

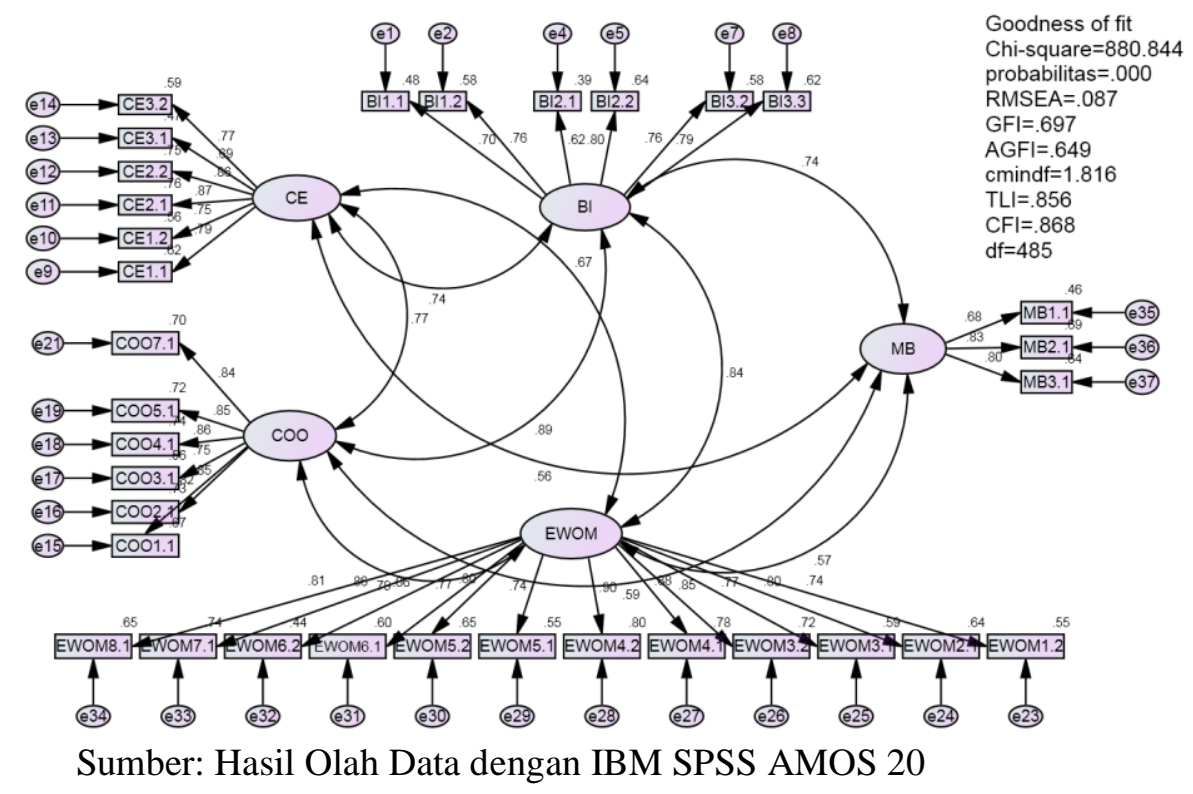

Gambar 1. ANALISIS FAKTOR KONFIRMATORI

Setelah item yang tidak valid di drop dan dilakukan analisis ulang (Gambar 1.) diperoleh data yang valid. Semua item memiliki nilai loading factor $\geq 0,55$. Tetapi hasil nilai goodness of fit index belum sesuai karena pada Gambar 1. hanya terdapat satu kriteria yang memenuhi dari delapan kriteria yang ada yaitu hanya indeks CMIN/DF. Oleh sebab itu model di atas dinyatakan kurang baik dan perlu dilakukan modifikasi model supaya di dapat model yang baik.

Cara meningkatkan model fit adalah tidak mengikutsertakan indikator yang loading factornya kecil atau dengan mendrop indikator yang memiliki nilai modification indices (MI) besar. Karena nilai loading factor semua item sudah diatas 0,55 maka untuk meningkatkan nilai goodness of fit dilakukan dengan menghapus beberapa error yang menjadi penyebab tidak fitnya model satu faktor karena memiliki koefisien modification indices besar (Umar \& Nisa, 2020). Berikut hasil modifikasi model: 
Jenia Hanindita Rahmawati \& Muhamad Ahsan. Demam Korea: Minat Beli terhadap Produk Kecantikan Korea (K-Beauty)

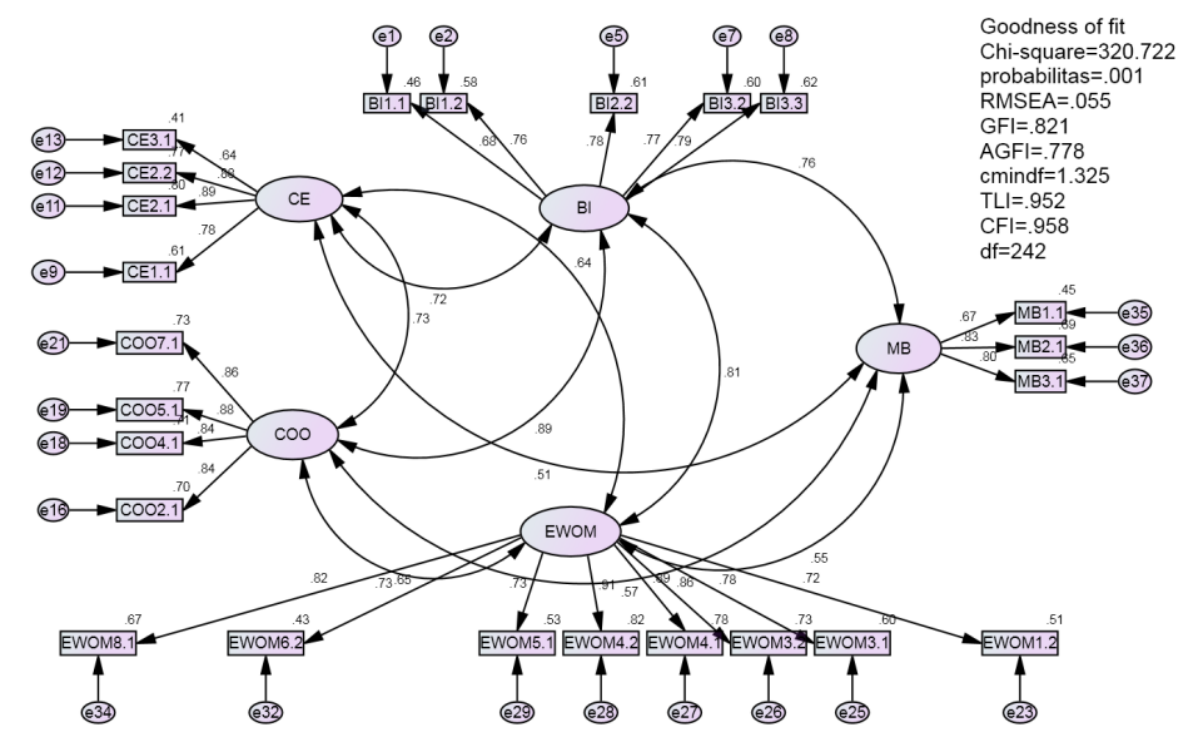

Sumber: Hasil Data Diolah dengan IBM SPSS AMOS 20

Gambar 2. MODIFIKASI CFA

Setelah dilakukan modifikasi model (Gambar 2), maka diperoleh nilai goodness of fit index setelah modifikasi yang diinterpretasikan pada tabel 1.

\section{Tabel 1.}

\section{GOODNESS OF FIT MODEL CFA SETELAH MODIFIKASI}

\begin{tabular}{lccc}
\hline \multicolumn{1}{c}{ Goodness of Fit Index } & Ketentuan & Hasil & Keterangan \\
\hline $\mathrm{X}^{2}$ Chi-square & Kecil $(*) \leq 279,2876$ & 320,722 & Less fit \\
Probabilitas & $\geq 0,05$ & 0,001 & Less fit \\
RMSEA & $\leq 0,08$ & 0,055 & Fit \\
GFI & $\geq 0,90$ & 0,821 & Marginal Fit \\
AGFI & $\geq 0,90$ & 0,778 & Less fit \\
CMIN/DF & $\leq 2,00$ & 1,325 & Fit \\
TLI & $\geq 0,95$ & 0,952 & Fit \\
CFI & $\geq 0,95$ & 0,958 & Fit \\
\hline
\end{tabular}

Sumber: Data diolah, 2021 (Output IBM SPSS AMOS 20)

Keterangan $(*)$ : diperoleh dari program excel, dengan $\mathrm{df}=242$ dan $\alpha=0,05$ adalah 279,2876

Tabel 1 menunjukkan perbaikan pada empat kriteria indeks dari delapan kriteria indeks yang ada yaitu CMIN/DF, RMSEA, TLI, CFI sudah fit. Sedangkan, GFI memenuhi syarat secara marginal. Menurut (Hair et al., 2010), setidaknya ada tiga indeks yang harus memenuhi kriteria fit agar model penelitian dapat dikatakan baik. Dari hasil modifikasi terdapat empat kriteria indeks yang fit, maka model penelitian ini dinyatakan baik dan dapat dilakukan analisis berikutnya.

\section{Uji Model pengukuran SEM: Uji Reliabilitas}

Uji Reliabilitas dilihat dari nilai Construct Reliability (CR) dengan syarat $\geq 0,7$ dan Variance Extracted (VE) dengan syarat $\mathrm{VE} \geq 0,5$. Nilai $\mathrm{CR}$ variabel brand image 0,871 , variabel celebrity endorser 0,879 , variabel country of origin 0,916 , variabel electronic word of mouth 0,932 , variabel minat beli 0,814. Dan nilai VE variabel brand image 0,575, variabel celebrity endorser 0,648, variabel country of origin 0,731 , variabel electronic word of mouth 0,635 , variabel minat beli 0,595. Dari nilai tersebut dapat dinyatakan bahwa instrumen penelitian ini reliabel. 


\section{Uji Model Struktural (Structural Model)}

Uji model struktural dilakukan agar diketahui keputusan dari hipotesis yang telah diajukan. Tabel 2 memuat nilai probability (P) dan critical ratio (C.R) untuk menentukan pengaruh, diterima atau tidaknya hipotesis. Diterima jika P (sig.) $<0,05$ dan C.R $>1,96$. Nilai estimate "standardized regression weights" untuk melihat arah pengaruh, serta memuat keputusan dari hipotesis yang telah diasumsikan. Berikut hasil uji model struktural yang telah dilakukan.

Tabel 2.

HASIL UJI HIPOTESIS

\begin{tabular}{lcccc}
\hline \multicolumn{1}{c}{ Hipotesis } & $\begin{array}{c}\text { Standardized } \\
\text { Regression } \\
\text { Weights }\end{array}$ & C.R. & P & Keputusan \\
\hline H1: MB <--- BI & 1,401 & 3,086 & 0,002 & diterima \\
H2: MB <--- CE & 0,055 & 0,348 & 0,728 & ditolak \\
H3: MB <--- COO & $-0,585$ & $-1,745$ & 0,081 & ditolak \\
H4: MB<--- EWOM & $-0,195$ & $-0,947$ & 0,330 & ditolak \\
\hline
\end{tabular}

Sumber: Data diolah, 2021 (Output IBM SPSS AMOS 20)

\section{Analisis Angka Indeks}

Analisis angka indeks berfungsi sebagai analisis deskriptif guna mengetahui persepsi responden atas item-item pertanyaan pada variabel yang diteliti. Berikut hasil nilai indeks tersaji pada Tabel 3.

Tabel 3.

INDEKS VARIABEL PENELITIAN

\begin{tabular}{|c|c|c|c|c|c|c|c|}
\hline Variabel & Item & Indeks & Kategori & Variabel & Item & Indeks & Kategori \\
\hline \multirow{6}{*}{ Image } & BI1.1 & 92,3 & Tinggi & & EWOM1.2 & 96,8 & Tinggi \\
\hline & BI1.2 & 92,8 & Tinggi & & EWOM3.1 & 88,5 & Tinggi \\
\hline & BI2.2 & 96,8 & Tinggi & & EWOM3.2 & 94,2 & Tinggi \\
\hline & BI3.2 & 92 & Tinggi & & EWOM4.1 & 94 & Tinggi \\
\hline & BI3.3 & 95,8 & Tinggi & Electronic & EWOM4.2 & 94,4 & Tinggi \\
\hline & Mean & 93,94 & Tinggi & Word of & EWOM5.1 & 91,3 & Tinggi \\
\hline \multirow{5}{*}{$\begin{array}{l}\text { Celebrity } \\
\text { Endorser }\end{array}$} & CE1.1 & 87 & Tinggi & Mouth & EWOM6.2 & 92,2 & Tinggi \\
\hline & CE2.1 & 88,1 & Tinggi & & EWOM8.1 & 92 & Tinggi \\
\hline & CE2.2 & 88,1 & Tinggi & & Mean & 93,01 & Tinggi \\
\hline & CE3.1 & 94,1 & Tinggi & & & & \\
\hline & Mean & 89,3 & Tinggi & & & & \\
\hline \multirow{5}{*}{$\begin{array}{l}\text { Country } \\
\text { of Origin }\end{array}$} & $\mathrm{COO} 2.1$ & 96,6 & Tinggi & & MB1.1 & 88,2 & Tinggi \\
\hline & COO4.1 & 93,8 & Tinggi & & MB2.1 & 85,2 & Tinggi \\
\hline & COO5.1 & 93,5 & Tinggi & Minat Beli & MB3.1 & 74,6 & Tinggi \\
\hline & COO7.1 & 94,7 & Tinggi & & Mean & 82,7 & Tinggi \\
\hline & Mean & 94 & Tinggi & & & & \\
\hline
\end{tabular}

Sumber: Data diolah (2021)

\section{Pengaruh Brand Image terhadap Minat Beli}

Uji hipotesis menunjukkan hasil, pengaruh brand image terhadap minat beli positif dan signifikan. Maka H1 diterima. Dapat diartikan bahwa, semakin positif brand image sebuah produk maka semakin tinggi minat beli konsumen. Hasil tersebut mendukung hasil riset terdahulu oleh Juliana et al.,(2018), Agatha et al., (2019) Berlianto (2019), Qonita (2019), Yusron et al., (2019), Ambarwati (2020), Benowati \& Purba (2020) dan Cahyaningrum (2020) bahwa pengaruh yang dimiliki brand image pada minat beli positif dan signifikan.

Dari indeks jawaban variabel brand image, tingginya minat beli responden dikarenakan produk kecantikan Korea selalu menghadirkan inovasi baru pada produk-produknya. Dari Tabel 3. Tampak 
bahwa item B12.2 (Produk kecantikan Korea memiliki inovasi baru) memiliki nilai indeks terbesar. Dengan adanya inovasi baru dapat membuat produk kecantikan Korea unik/berbeda dari produk lainnya, sehingga menimbulkan ketertarikan yang berdampak pada minat beli. Inovasi produk adalah produk lama yang dikembangkan oleh perusahaan atau industri karena mengalami titik jenuh yang kemudian didesain ulang menjadi lebih moderen dan up to date. Beberapa bentuk inovasinya adalah dengan hadirnya BB cream, cushion compacts, sheet mask, eye mask, exfoliator, dan lain-lain. Merek produk kecantikan Korea yang paling banyak diminati responden ialah SOME BY MI dan Nature Republic sedangkan untuk jenis produk kecantikan Korea yang paling diminati ialah serum.

Dari hasil CFA pada gambar 2 nilai loading factor item BI3.3 (citra produk Korea baik) pada indikator keunggulan/favorable memberikan konstribusi terbesar dalam menjelaskan konstruk brand image. Dapat dimaknai bahwa pada kelompok variabel brand image, menurut responden hal yang paling penting yaitu citra/image produk. Maka rekomendasi yang dapat diberikan bagi pelaku usaha produk kecantikan untuk dapat meningkatkan minat beli konsumen yaitu menciptakan, mempertahankan, meningkatkan dan melindungi merek agar memiliki image yang baik. Merek yang memiliki citra positif/baik akan dianggap sebagai produk yang dapat diandalkan oleh konsumen.

\section{Pengaruh Celebrity Endorser terhadap Minat Beli}

Uji hipotesis menunjukkan hasil, celebrity endorser tidak berpengaruh terhadap minat beli. Maka $\mathrm{H} 2$ ditolak. Hasil tersebut mendukung hasil riset terdahulu oleh Astuti et al., (2021) jika pengaruh celebrity endorser pada minat beli tidak signifikan. Serta penelitian Qonita (2019) bahwa celebrity endorser tidak memengaruhi minat beli.

Beberapa alasan yang menjadikan variabel celebrity endorser tidak memengaruhi minat beli adalah: 1). Dari indeks jawaban responden variabel celebrity endorser pada Tabel 3. bahwa item CE1.1 (celebrity endorser meyakinkan dan membuat saya percaya pada kualitas produk yang ada) memiliki nilai indeks terendah diantara item pertanyaan lainnya. Hal tersebut menunjukkan bahwa responden kurang yakin dan percaya pada informasi produk yang disampaikan celebrity endorser, dikarenakan pesan produk yang disampaikan hanya hal-hal positifnya saja. Sehingga ketika produk kecantikan tersebut digunakan, hasil atau manfaatnya terkadang tidak sesuai dengan informasi yang diberikan yang akhirnya membuat responden ragu terhadap kualitas produk tersebut. 2). Dari hasil riset Zap Beauty Index bahwa 54,2\% panutan wanita Indonesia di bidang kecantikan adalah beauty influencers Indonesia. Sedangkan 29,1\% wanita menjadikan ibu mereka sebagai inspirasi di dunia kecantikan, lalu selebriti mancanegara sebesar $24,7 \%$ dan selebriti Indonesia sebesar 18,1\%. Penelitian ini tentang produk kecantikan asal Korea Selatan, dimana sebagian besar celebrity endorser-nya adalah artis Korea Selatan yang merupakan selebriti mancanegara. Persentase wanita Indonesia yang menjadikan selebriti mancanegara sebagai panutannya memiliki persentase kecil hanya $24,7 \%$. Hal tersebut membuat variabel celebrity endorser tidak lagi memengaruhi minat beli pada produk kecantikan Korea dikarenakan sebagian besar panutan wanita Indonesia ialah beauty influencers Indonesia (Zapclinic.com, 2020).

Dari hasil CFA pada gambar 2 nilai loading factor item CE2.1 (celebrity endorser memiliki keterampilan dan pengalaman dalam mempromosikan produk) pada indikator Expertise/keahlian memberikan konstribusi terbesar dalam menjelaskan variabel laten celebrity endorser. Sedangkan item CE2.2 (celebrity memiliki pengetahuan yang baik dalam menyampaikan pesan endorsement) mengenai pengetahuan celebrity endorser memiliki loading factor tertinggi kedua yang juga termasuk indikator Expertise (keahlian). Hal tersebut dapat dimaknai bahwa pada kelompok variabel celebrity endorser, menurut responden hal yang paling penting adalah keahlian selebriti dalam mengendors produk. Maka rekomendasi yang dapat diberikan bagi pelaku usaha produk kecantikan untuk dapat menarik minat beli konsumen adalah, dalam memilih celebrity endorser sebaiknya tidak hanya melihat popularitas ataupun tampilan fisik selebriti semata akan tetapi perlu juga melihat keahliannya. Seorang selebriti yang memiliki keahlian dalam mempromosikan produk (keterampilan, pengalaman dan pengetahuan) akan membuat pesan yang disampaikan lebih dapat dipercaya dan diterima oleh konsumen. Serta akan mampu menciptakan persepsi produk yang baik pada benak konsumen. Selebriti yang mempunyai keahlian akan lebih persuasif dalam menarik audience. 


\section{Pengaruh Country of Origin terhadap Minat Beli}

Uji hipotesis menunjukkan hasil, country of origin tidak berpengaruh terhadap minat beli. Maka $\mathrm{H} 3$ ditolak. Hasil ini mendukung penelitian Berlianto (2019) dan Widianingsih \& Astuti (2021) bahwa country of origin tidak memengaruhi minat beli pada produk kosmetik.

Beberapa alasan yang membuat variabel country of origin menjadi tidak memengaruhi minat beli adalah: 1). Terdapat faktor-faktor yang memengaruhi konsumen terhadap country of origin dari suatu merek diantaranya ialah faktor kelas sosial dan ekonomi. Seseorang dengan ekonomi sosial yang tinggi dipersepsikan lebih memiliki akses untuk memperoleh informasi, terbuka dengan budaya lain, sering bepergian yang membuat mereka lebih memperhatikan dan menyadari produk bermerek Internasional dan negara asal merek suatu produk (Setyaningsih et al., 2007). Sedangkan jika dilihat dari karakteristik responden bahwa sebagian besar pendapatan orang tua responden (43\%) sebesar Rp1.000.000 sampai Rp3.000.000. Pendapatan ini berada pada tingkatan menengah ke bawah yang berdampak pada jumlah uang saku yang diberikan kepada mahasiswa setiap bulannya. Sebanyak 59\% mahasiswa memperoleh uang saku per bulan <Rp500.000. Dapat dinyatakan bahwa responden bukanlah dari kalangan kelas sosial ekonomi yang tinggi, sehingga responden kurang memperhatikan dan menyadari berbagai merek produk Internasional dan negara asalnya. 2). Preferensi konsumen dalam menentukan produk kecantikan dipengaruhi oleh dua aspek, diantaranya ialah aspek kebutuhan. Aspek kebutuhan yaitu bagaimana produk kecantikan tersebut mampu memenuhi kebutuhan konsumen, misalnya kebutuhan akan kulit mereka sampai bagaimana produk tersebut mampu mengatasi permasalahan kulit (Syauki \& Avina, 2020). Hal tersebut membuat konsumen kurang memperhatikan asal negara produk, karena darimanapun negara asal produk kecantikan, asalkan produknya cocok/sesuai dengan kebutuhan konsumen, maka konsumen akan tetap menginginkannya.

Dari hasil CFA pada gambar 2 nilai loading factor indikator COO5.1 (kualitas produksi) memberikan konstribusi terbesar dalam menjelaskan variabel laten country of origin. Maka rekomendasi yang dapat diberikan kepada pelaku bisnis produk kecantikan sebaiknya tetap menjaga dan meningkatkan kualitas produk. Sehingga memiliki citra sebagai negara yang memiliki produk berkualitas. Sebab, konsumen yang sensitif terhadap negara asal produk seperti sosialita atau kalangan ekonomi atas yang lebih memperhatikan dan menyadari merek-merek internasional, akan memperhatikan negara asal dari merek suatu produk untuk menilai kualitas merek dari produk yang akan dipilih.

\section{Pengaruh Electronic Word of Mouth terhadap Minat Beli}

Uji hipotesis menunjukkan hasil, electronic word of mouth tidak berpengaruh terhadap minat beli. Maka H4 ditolak. Temuan ini menguatkan hasil penelitian Indana \& Andjarwati (2021), Majid \& Rofiq (2013) yang menyatakan electronic word of mouth tidak memengaruhi minat beli.

Alasan yang membuat variabel electronic word of mouth menjadi tidak memengaruhi minat beli dapat dilihat pada indeks jawaban responden Tabel 3. Jawaban item EWOM3.1 mengenai rekomendasi produk memiliki nilai indeks terendah diantara item pertanyaan lainnya. Hal tersebut dimaknai bahwa rekomendasi yang diberikan oleh konsumen lain di internet kurang memberi pengaruh terhadap minat beli. Sedangkan berdasarkan karakteristik responden, kebanyakan responden mengetahui produk $K$ Beauty dari media sosial Instagram (70\%), dari Youtube (21\%), dari Twitter (5\%) dan dari Tik Tok (4\%). Dimana pada media sosial tersebut terdapat rekomendasi produk dari review/ulasan yang diberikan oleh konsumen yang pernah menggunakan melalui komentar, postingan atau konten di media sosial. Rekomendasi ini merupakan bentuk kredibilitas electronic word of mouth, yaitu seberapa jauh konsumen tersebut mempercayai rekomendasi dari orang lain. Konsumen yang percaya pada rekomendasi tersebut (baik komentar dan saran) maka akan melakukan pembelian (Benowati \& Purba, 2020). Sedangkan rekomendasi yang diberikan konsumen lain di internet kebanyakan bukanlah orang yang dikenal/anonim. Hal tersebut menimbulkan kepercayaan yang rendah dan membuat konsumen ragu sehingga minat beli menurun. Pada komunikasi electronic word of mouth, pengguna media sosial tidak bisa melihat bukti nyata dan rawan manipulasi. Sebagai contoh, konsumen di internet memberi rekomendasi terkait sabun pemutih tetapi kondisi sebenarnya pengguna produk tersebut memang sudah memiliki kulit yang putih atau melebih-lebihkan informasi seperti "jika 
Jenia Hanindita Rahmawati \& Muhamad Ahsan. Demam Korea: Minat Beli terhadap Produk Kecantikan Korea (K-Beauty)

menggunakan produk ini bisa putih permanen atau putih instan" tetapi ternyata ketika dicoba hasilnya tidak sesuai dengan informasi yang ada.

Dari hasil CFA pada Gambar 2 nilai loading factor indikator expressing positive feelings (EWOM4.2) memberikan konstribusi terbesar dalam menjelaskan variabel laten electronic word of mouth. Dapat dimaknai, hal paling penting menurut responden adalah extraversion/positive selfenhancement/ekspresi perasaan positif. Maka rekomendasi yang dapat diberikan bagi pelaku usaha produk kecantikan untuk dapat menarik minat beli konsumen adalah sering mengunggah informasi tentang produk dan mengajak followers memberikan ulasan positif. Ulasan positif/expressing positive feelings dari konsumen yang sesungguhnya dapat membuat calon konsumen merasa bahwa produk tersebut merupakan pilihan yang tepat.

\section{KESIMPULAN}

Pengaruh brand image pada minat beli produk kecantikan Korea (K-Beauty), positif dan signifikan. Sedangkan celebrity endorser, country of origin dan electronic word of mouth tidak berpengaruh pada minat beli produk kecantikan Korea (K-Beauty). Untuk menjaga dan meningkatkan minat beli kosmetik Korea, yang perlu dilakukan pelaku bisnis produk kecantikan adalah terus membangun dan memperhatikan brand image produk yang dijual agar memiliki citra merek yang positif. Implikasi praktis yang harus dilakukan untuk meningkatkan minat beli, yang perlu dilakukan pelaku bisnis produk kecantikan adalah 1) merekrut celebrity endorser yang ahli dalam mempromosikan produk sehingga lebih persuasif dalam menarik audience. 2) sering mengunggah informasi tentang produk, dan mengajak followers memberi ulasan positif yang dapat memengaruhi minat beli calon konsumen. 3) meningkatkan kualitas produk agar memiliki citra sebagai negara produsen yang berkualitas sehingga menarik minat beli calon konsumen yang menjadikan country of origin sebagai penentu sebelum melakukan pembelian.

Keterbatasan dalam penelitian ini adalah menggunakan metode survei dengan tipe kuesioner tertutup sehingga tidak mengetahui alasan dibalik persepsi setuju dan tidak setuju. Bagi penelitian berikutnya alangkah baiknya menambah variabel yang hendak diteliti seperti korean wave, kualitas produk, word of mouth dan gaya hidup serta dikembangkan lebih mendalam seperti mengukur tentang keputusan pembelian ataupun niat beli ulang. Selain itu, memperluas populasi dan meningkatkan jumlah sampel agar lebih representatif.

\section{DAFTAR PUSTAKA}

Aaker, D. A. (1997). Manajemen Ekuitas Merek: Memanfaatkan Nilai dari Suatu Merek. Jakarta: Mitra Utama.

Agatha, C., Tumbel, A., \& Soepeno, D. (2019). Pengaruh Brand Image dan Electronic Word of Mouth Terhadap Minat Beli Konsumen Oriflame di Manado. Jurnal EMBA: Jurnal Riset Ekonomi, Manajemen, Bisnis dan Akuntansi, 7(1), 131-140. https://doi.org/10.35794/emba.v7i1.22291

Ambarwati, O. D. (2020). Pengaruh Electronic Word of Mouth dan Brand Image Terhadap Purchase Intention Produk Nature Republic. Volatilitas, 2(2), 1-13.

Assael, H. (2002). Consumer Behavior and Marketing Action. Boston: PWS-Kent Publishing.

Astuti, S. M. K., Lukitaningsih, A., \& Hutami, L. T. H. (2021). Analisis Pengaruh Celebrity Endorse, Beauty Vlogger, Word of Mouth, dan Brand Image Terhadap Minat Beli Produk Emina. Jurnal Ilmiah Manajemen Kesatuan, 9(1), 53-62. https://doi.org/10.37641/jimkes.v9i1.439

Benowati, S. G., \& Purba, T. (2020). Pengaruh Citra Merek dan Electronic Word of Mouth Terhadap Minat Beli Kosmetik Wardah di Kota Batam. Jurnal Ilmiah Ekonomi Dan Bisnis Triangle, 
$1(2), 356-370$.

Berlianto, M. P. (2019). Pengaruh Country of Oringin dan Brand Image Terhadap Brand Equity dan Niat Pembelian pada Produk Kosmetik. Journal of Business \& Applied Management, 12(1), 59-70. http://dx.doi.org/10.30813/jbam.v12i01.1618

Budiarti, L. (2020). Pengaruh Negara Asal Terhadap Minat Pembelian Produk Kosmetik Impor dengan Moderasi Variabel Pengetahuan Produk. Adbis: Jurnal Administrasi dan Bisnis, 14(1), 33-39. http://dx.doi.org/10.33795/j-adbis.v14i1.86

Cahyaningrum, F. (2020). Analisis Pengaruh Electronic Word of Mouth, Celebrity Endorser dan Country of Origin Terhadap Purchase Intention Melalui Brand Image di Wardah Beauty House Semarang. Prosiding Konferensi Ilmiah Mahasiswa Unissula (KIMU) 3, 851-871. http://jurnal.unissula.ac.id/index.php/kimue/article/view/10471

Durianto, D. (2013). Strategi Menaklukkan Pasar Melalui Riset Ekuitas dan Perilaku Merek. Jakarta: Gramedia Pustaka Utama.

Fauziah, N., \& Mubarok, D. A. A. (2019). Pengaruh Citra Merek Terhadap Minat Beli: Studi pada Produk Kecantikan. Image: Jurnal Riset Manajemen, 8(1), 37-44. https://doi.org/10.17509/image.v8i1.22686

Ferdinand, A. (2014). Metode Penelitian Manajemen, Pedoman Penelitian untuk Penulisan Skripsi, Tesis dan Disertasi Ilmu Manajemen. Semarang: Badan Penerbit Universitas Diponegoro.

Gareta, S. P. (2021). Kemenperin: Industri Kosmetik Tumbuh Signifikan pada 2020. antaranews.com. (https://www.antaranews.com/berita/2003853/kemenperin-industri-kosmetik-tumbuhsignifikan-pada-2020\#: :text=Jakarta (ANTARA) - Direktur Jenderal,termasuk di dalamnya\%2C tumbuh 9, diakses pada 12 Maret 2021)

Gruen, T. W., Osmonbekov, T., \& Czaplewski, A. J. (2006). eWOM: The Impact of Customer-toCustomer Online Know-How Exchange on Customer Value and Loyalty. Journal of Business research, 59(4), 449-456. https://doi.org/10.1016/j.jbusres.2005.10.004

Hair, J. F., Black, W. C., Babin, B. J., \& Anderson, R. E. (2010). Multivariate Data Analysis 7th Edition. New Jersey: Pearson Prentice Hall.

Hair, J. F., Black, W. C., Babin, B. J., \& Anderson, R. E. (2018). Multivariate Data Analysis, Eight Edition. United Kingdom: Pearson Education.

Hennig-Thurau, T., Gwinner, K. P., Walsh, G., \& Gremler, D. D. (2004). Electronic Word-of-Mouth Via Consumer-Opinion Platforms: What Motivates Consumers to Articulate Themselves on The Internet? Journal of interactive marketing, 18(1), 38-52. https://doi.org/10.1002/dir.10073

Howard, J. A., \& Sheth, J. N. (1969). The Theory of Buyer Behavior. New York: John Wiley \& Sonds, Inc.

Husna, R., \& Dirgantara, I. M. B. (2018). Analisis Pengaruh Electronic Word of Mouth di Media Sosial Youtube Terhadap Minat Beli Produk Kosmetik Sariayu. Diponegoro Journal of Management, 7(3), 95-109.

Imaningsih, E. S., \& Rianty, E. (2018). Pengaruh Persepsi Harga, Citra Merek dan Citra Negara Asal Terhadap Minat Pembelian Body Butter The Body Shop. Jurnal Ilmiah Manajemen dan Bisnis, 4(3), 309-323. https://dx.doi.org/10.22441/jimb.v4i3.5610 
Jenia Hanindita Rahmawati \& Muhamad Ahsan. Demam Korea: Minat Beli terhadap Produk Kecantikan Korea (K-Beauty)

Indana, L., \& Andjarwati, A. L. (2021). Website Quality, Brand Image, dan E-WOM Serta Pengaruhnya Terhadap Online Purchase Intention Studi Pengunjung Website Berrybenka. Jurnal Ilmu Manajemen, 9(2), 536-546. https://doi.org/10.26740/jim.v9n2.p536-546

Juliana, A. D., Hubner, I. B., \& Noval, T. (2018). Pengaruh Celebrity Endorser dan Brand Image Terhadap Purchase Intention Produk Kosmetik Etude House pada Mahasiswi Sekolah Tinggi Pariwisata Pelita Harapan Karawaci. Jurnal Ilmiah Skylandse, 2(2), 251-256.

Keller, K. L. (2013). Strategic Brand Management: Building, Measuring, and Managing Brand Equity (Fourth edi). USA: Pearson.

Kotler, P., \& Keller, K. L. (2007). Manajemen Pemasaran, Edisi 12 Jilid 2. Jakarta: PT Indeks.

Kotler, P., \& Keller, K. L. (2009). Manajemen Pemasaran, Edisi 13. Jakarta: Erlangga.

Lusk, J. L., Brown, J., Mark, T., Proseku, I., Thompson, R., \& Welsh, J. (2006). Consumer Behavior, Public Policy, and Country-of-Origin Labeling. Review of agricultural economics, 28(2), 284292. http://dx.doi.org/10.2307/3700760

Majid, N., \& Rofiq, A. (2013). Analisis Pengaruh Electronic Word of Mouth Terhadap Brand Image dan Dampaknya pada Minat Beli Smartphone Samsung di Kota Malang. Jurnal Ilmiah Mahasiswa FEB, 2(2), 1-13.

McCracken, G. (1989). Who Is The Celebrity Endorser? Cultural Foundations of The Endorsement Process. Journal of consumer research, 16(3), 310-321. https://doi.org/10.1086/209217

Pradana, Y. S. (2020). Menelisik Tren Peningkatan Pengguna Internet di Indonesia. goodnewsformindonesia.id. (https://www.goodnewsfromindonesia.id/2020/08/26/menelisiktren-peningkatan-pengguna-internet-di-indonesia, diakses pada 20 November 2020)

Qonita, A. (2019). Analisis Pengaruh Iklan, Celebrity Endorser dan Citra Merek Terhadap Minat Beli Wardah Kosmetik. Jurnal Ekobis Dewantara, 1(8), 121-131.

Ramlawati, R., \& Lusyana, E. (2020). Pengaruh Celebrity Endorsement dan Citra Merek Terhadap Minat Beli Produk Kecantikan Wardah pada Mahasiswi Hpmm Cabang Maiwa Di Makassar. MANOR: Jurnal Manajemen dan Organisasi Review, 2(1), 65-75.

Royan, F. M. (2004). Marketing Selebrities. Jakarta: Elex Media Komputindo.

Santoso, D. A., Erdiansyah, R., \& Pribadi, M. A. (2019). Pengaruh Brand Awareness dan Brand Image terhadap Minat Beli Produk Kecantikan Innisfree. Prologia, 2(2), 286-290. http://dx.doi.org/10.24912/pr.v2i2.3589

Setyaningsih, R., Mangunwihardjo, S., \& Soesanto, H. (2007). Analisis Faktor-Faktor yang Mempengaruhi Ekuitas Merek untuk Meningkatkan Minat Beli Ulang (Studi Kasus pada Kedai Kopi Dome di Surabaya). Jurnal Studi Manajemen Organisasi, 4(2), 30-43. https://doi.org/10.14710/jsmo.v4i2.4247

Shimp, T. A. (2003). Periklanan dan Promosi: Aspek Tambahan Komunikasi Pemasaran Terpadu. Jakarta: Erlangga.

Syauki, W. R., \& Avina, D. A. A. (2020). Persepsi dan Preferensi Penggunaan Skincare pada Perempuan Milenial dalam Perspektif Komunikasi Pemasaran. Jurnal Manajemen Komunikasi, 4(2), 42-60. https://doi.org/10.24198/jmk.v4i2.25719 
Umar, J., \& Nisa, Y. F. (2020). Uji Validitas Konstruk dengan CFA dan Pelaporannya. JP3I (Jurnal Pengukuran Psikologi dan Pendidikan Indonesia), 9(2), 1-11. https://doi.org/10.15408/jp3i.v9i2.16964

Widianingsih, A., \& Astuti, H. J. (2021). Pengaruh Endorsement Beauty Vlogger, Country of Origin dan Perceived Quality Terhadap Minat Beli Produk Kosmetik Mascara Maybelline (Studi pada Mahasiswa di Beberapa Universitas di Purwokerto). Master: Jurnal Manajemen dan Bisnis Terapan, 1(1), 23-34. http://dx.doi.org/10.30595/jmbt.v1i1.10403

Yasin, N. M., Noor, M. N., \& Mohamad, O. (2007). Does Image of Country-of-Origin Matter to Brand Equity? Journal of Product \& brand management, 16(1), 38-48. https://doi.org/10.1108/10610420710731142

Yusron, S., Rachma, N., \& Hufron, M. (2019). Pengaruh Celebrity Endorser Terhadap Minat Beli Melalui Citra Merek Sebagai Variabel Intervening pada Pengguna Kosmetik Pixy di Toko Aster Malang. Jurnal Ilmiah Riset Manajemen, 8(9), 53-62.

Zapclinic.com. (2020). ZAP Beauty Index 2020. (https://zapclinic.com/zapbeautyindex/2020. Diakses pada 19 November 2020) 